\title{
MODEL HUBUNGAN TINGGI TEGAKAN DENGAN PENINGGI PADA HUTAN TANAMAN JATI (Tectona grandis L.f)
}

\author{
Model of Stand Height and Upper Height Relationship for Teak \\ (Tectona grandis L.f) Plantation Forest \\ Harbagung \\ Pusat Litbang Hutan Tanaman \\ Kampus Balitbang Kehutanan, Jl. Gunung Batu No. 5, Bogor \\ Telp. (0251) 631238, Fax. (0251) 7520005
}

Naskah masuk : 28 April 2008 ; Naskah diterima : 16 Februari 2009

\begin{abstract}
Diameter, height, upper height, and volume of the stand are important information resulted from forest plantation inventories. Among these, tree height, however, is relatively more difficult and time consuming to measure. This research was aimed to develop a model of stand height and upper height relationship for Teak (Tectona grandis L.f) plantation forest to make inventory work simpler. Result of homogenity analysis of the regression equations based on 12 plots aged 7, 18, 25, and 35 years from Sumedang Forest District, 12 plots aged 12, 19, 108, and 117 years from Kendal Forest District, 18 plots aged 7, 17, 60, 66, and 79 years from Blora Forest District, and 24 plots aged 17, 20, 30, 33, 44, 47, 65, and 68 years from Saradan Forest District showed that the equations of stand height (Hs) and upper height (Oh) relationships were not significantly different between sites. Therefore, a single equation was developed which could be applied to all sites, i.e. $H_{s}=-2.2852+1.0572 \mathrm{Oh}$, with the value of corrected determination coefficient was 0.998. Chi-square test using independent data suggested that the equation was relatively accurate for application.
\end{abstract}

Key words : forest plantation, model, stand height, teak (Tectona grandis L.f), upper height.

\begin{abstract}
ABSTRAK
Diameter, tinggi, peninggi, dan volume tegakan merupakan informasi penting yang perlu dihasilkan dari kegiatan inventarisasi hutan tanaman. Dalam pengumpulan data semua informasi tersebut, pengukuran tinggi pohon merupakan pekerjaan yang relatif sulit dan membutuhkan banyak waktu. Penelitian ini bertujuan menyusun model hubungan antara tinggi dengan peninggi tegakan hutan tanaman Jati (Tectona grandis L.f) agar pekerjaan inventarisasi dapat lebih sederhana. Hasil analisis keseragaman regresi terhadap 12 plot pada umur 7, 18, 25, dan 35 tahun di Kesatuan Pemangkuan Hutan (KPH) Sumedang, 12 plot pada umur 12, 19, 108, dan 117 tahun di KPH Kendal, 18 plot pada umur 7, 17, 60, 66, dan 79 tahun di KPH Blora, dan 24 plot pada umur 17, 20, 30, 33, 44, 47, 65, dan 68 tahun di KPH Saradan menunjukkan bahwa persamaan hubungan tinggi tegakan $(H s)$ dengan peninggi tegakan $(O h)$ hutan tanaman Jati tidak berbeda nyata antar lokasi, sehingga dapat disusun sebuah persamaan yang berlaku di semua lokasi, yaitu $H s=-2,2852+1,0572$ Oh, dengan koefisien determinasi terkoreksi sebesar 0,998. Uji $\chi^{2}$ dengan menggunakan data independent menunjukkan bahwa persamaan tersebut cukup sahih untuk penerapannya di lapangan.
\end{abstract}

Kata kunci : hutan tanaman, Jati (Tectona grandis L.f), model, peninggi, tinggi tegakan. 


\section{PENDAHULUAN}

\section{A. Latar Belakang}

Informasi yang akurat mengenai luas, sebaran, dan potensi tegakan sangat diperlukan dalam pengelolaan hutan tanaman. Kondisi tegakan di tiap petak tanaman biasanya digambarkan melalui parameter diameter setinggi dada $(D b h)$ dan tinggi tegakan $(H)$ yang merupakan gambaran penampilan individu pohon; peninggi $(\mathrm{Oh})$ merupakan indikator kualitas tapak (bonita); jumlah pohon $(N)$ dan luas bidang dasar, yang merupakan penjabaran dari diameter $\left(\sum \frac{1}{4} \mathrm{p} D b h^{2}\right)$, mencerminkan kerapatan tegakan; dan volume tegakan $\left(V=\sum f(D b h, H)\right)$ mencerminkan massa kayu.

Semua informasi tersebut diperoleh dari kegiatan inventarisasi hutan. Dalam praktek lapangan, biasanya inventarisasi hutan tanaman dilaksanakan dengan membuat plot-plot sampel yang diletakkan tersebar merata pada tiap petak tanaman. Pengukuran diameter semua pohon di dalam tiap plot sampel merupakan pekerjaan sederhana dengan hasil cukup akurat, sedangkan pengukuran tinggi pohon merupakan pekerjaan yang relatif sulit dan membutuhkan banyak tenaga. dan biaya karena: ${ }^{(1)}$ membutuhkan waktu relatif lama, ${ }^{(2)}$ mudah terjadi kesalahan pengukuran, dan ${ }^{(3)}$ hambatan visual akibat rapatnya penutupan tajuk (Colbert et al., 2002). Sehubungan dengan kendala tersebut maka perlu dicari teknik untuk meminimalkan pekerjaan pengukuran tinggi pohon, tanpa mengurangi kelengkapan dan keakuratan data yang harus disajikan.

Penyusunan model hubungan antara tinggi tegakan $(H)$ dengan peninggi $(O h)$ merupakan salah satu cara untuk mengurangi pekerjaan pengukuran tinggi pohon. Pekerjaan pengukuran tinggi pohon dapat diperkecil secara signifikan dengan membatasi pengukuran pohon-pohon yang dominan saja (tidak harus mengukur tinggi semua pohon), sedangkan pengukuran peninggi perlu dipertahankan mengingat kegunaannya sebagai indikator atau kunci pembacaan kualitas tempat tumbuh (bonita).

\section{B. Tujuan Penelitian}

Penelitian ini bertujuan untuk menyusun model hubungan tinggi dengan peninggi tegakan hutan tanaman Jati (Tectona grandis L.f) yang cukup sahih dengan menggunakan data yang dikumpulkan di Kesatuan Pemangkuan Hutan (KPH) Sumedang, KPH Kendal, KPH Blora, dan KPH Saradan.

\section{BAHAN DAN METODE}

\section{A. Lokasi Penelitian}

Penelitian dilakukan pada beberapa lokasi tegakan hutan tanaman Jati (T. grandis L.f) yang dikelola oleh Perum Perhutani, yaitu di Kesatuan Pemangkuan Hutan (KPH) Sumedang, KPH Kendal, KPH Blora, dan KPH Saradan. Rincian risalah lokasi penelitian baik secara administrasi pengelolaan kawasan hutan maupun administrasi pemerintahan dapat dilihat pada Lampiran 1, dan deskripsi keadaan lingkungan masing-masing lokasi penelitian tertera pada Lampiran 2.

\section{B. Bahan Penelitian}

Deskripsi sebaran umur tegakan hutan tanaman Jati (T. grandis L.f) yang dijadikan bahan penelitian di masing-masing lokasi dengan keterangan sistem penanaman dan jarak tanamnya dapat dilihat pada Tabel 1. Semua tegakan tersebut mendapat perlakuan penjarangan sesuai dengan Pedoman Penjarangan Hutan Industri (Anonim, 1986). 


\section{Pengumpulan Data}

Petak-petak tanaman sebagai obyek penelitian dipilih secara sengaja (purposif) untuk memperoleh sebaran kelas umur selebar mungkin dengan mempertimbangkan ketersediaan tegakan di lapangan.

Tabel(Table) 1: Deskripsi tegakan hutan tanaman Jati yang dijadikan bahan penelitian (Description of teak stands used for study)

\begin{tabular}{|c|c|c|c|c|c|}
\hline $\begin{array}{c}\text { KPH } \\
\text { (Forest } \\
\text { District) }\end{array}$ & $\begin{array}{c}\text { RPH } \\
\text { (Forest } \\
\text { Resort) }\end{array}$ & $\begin{array}{l}\text { Petak tanaman } \\
\text { (Compartment) }\end{array}$ & $\begin{array}{l}\text { Umur tegakan } \\
\text { (Stand age) } \\
\text { (tahun/years) }\end{array}$ & $\begin{array}{c}\text { Sistem } \\
\text { tanam } \\
(\text { Planting } \\
\text { system })\end{array}$ & $\begin{array}{c}\text { Jarak } \\
\text { tanam } \\
\text { Spacing) } \\
(\mathrm{m})\end{array}$ \\
\hline Sumedang & $\begin{array}{l}\text { Cipelang } \\
\text { Suka Denda } \\
\text { Ujung Jaya } \\
\text { Sempora }\end{array}$ & $\begin{array}{c}43 \\
6 \mathrm{a} \\
30 \mathrm{a} \\
3\end{array}$ & $\begin{array}{c}7 \\
18 \\
25 \\
35\end{array}$ & $\begin{array}{l}\text { tumpangsari } \\
\text { tumpangsari } \\
\text { tumpangsari } \\
\text { tumpangsari }\end{array}$ & $\begin{array}{l}3 \times 1 \\
3 \times 1 \\
3 \times 1 \\
3 \times 1\end{array}$ \\
\hline Kendal & Subah & $\begin{array}{l}25 \mathrm{a} \\
26 \mathrm{a} \\
35 \mathrm{a} \\
36 \mathrm{a}\end{array}$ & $\begin{array}{c}12 \\
19 \\
108 \\
117\end{array}$ & $\begin{array}{l}\text { tumpangsari } \\
\text { tumpangsari } \\
\text { komplangan } \\
\text { komplangan }\end{array}$ & $\begin{array}{l}3 \times 1 \\
3 \times 1 \\
2 \times 1 \\
2 \times 1\end{array}$ \\
\hline Blora & Sumberejo & $\begin{array}{l}108 \mathrm{a} \\
109 \mathrm{c} \\
107 \mathrm{~b} \\
107 \mathrm{a} \\
106 \mathrm{a}\end{array}$ & $\begin{array}{c}7 \\
17 \\
59 \\
66 \\
79\end{array}$ & $\begin{array}{l}\text { tumpangsari } \\
\text { tumpangsari } \\
\text { tumpangsari } \\
\text { tumpangsari } \\
\text { tumpangsari }\end{array}$ & $\begin{array}{l}3 \times 1 \\
3 \times 1 \\
3 \times 1 \\
3 \times 1 \\
3 \times 1\end{array}$ \\
\hline Saradan & Sugihwaras & $\begin{array}{l}5 \mathrm{~b} \\
1 \mathrm{a} \\
5 \mathrm{c} \\
10\end{array}$ & $\begin{array}{l}17 \\
30 \\
44 \\
65\end{array}$ & $\begin{array}{l}\text { tumpangsari } \\
\text { tumpangsari } \\
\text { tumpangsari } \\
\text { tumpangsari }\end{array}$ & $\begin{array}{l}2 \times 1 \\
3 \times 1 \\
3 \times 1 \\
3 \times 1\end{array}$ \\
\hline
\end{tabular}

${ }^{*}$ Keterangan (Notes) : tumpangsari (taungya system), buah Jati ditanam langsung di lapangan yang sudah dipersiapkan untuk penanaman palawija dan anakan Jati tumbuh bersama tanaman palawija sampai umur 2 tahun (mixed cultivation (taungya system), the teak seeds planted directly on land prepared for planting food crops, the crops are allowed to grow between teak seedlings up to 2 years after planting) komplangan: buah Jati ditanam langsung di petak bekas tebangan dengan penyiapan lahan hanya berupa pembabatan belukar (komplangan, teak seeds planted directly on the logged-over land prepared with shrub clearing only)

Pengumpulan data dilakukan dengan membuat petak-petak ukur temporer (temporary sample plots - TSP) berbentuk bujur sangkar ukuran $40 \mathrm{~m} \times 40 \mathrm{~m}$ yang merupakan rangkaian 16 buah plot ukuran $10 \mathrm{~m}$ x $10 \mathrm{~m}$. Dalam 1 petak tanaman, jarak antar TSP ditentukan $100 \mathrm{~m}$, sedangkan jumlahnya tidak ditentukan tetapi tergantung pada luas dan bentuk areal petak tanaman.

Semua pohon di dalam TSP dipetakan letaknya (peta letak pohon), serta diukur diameter batang setinggi dada (1,30 $\mathrm{m}$ di atas tanah) dan tingginya. Alat yang dipergunakan untuk mengukur diameter batang adalah phi-band (pita-phi), sedangkan pengukuran tinggi pohon dilakukan dengan hagameter. 


\section{Analisis Data}

\section{Pemilahan data}

Himpunan data TSP di masing-masing lokasi penelitian dipilah secara random menjadi 2 kelompok, yaitu 70\% digunakan untuk menyusun persamaan regresi dan 30\% ditempatkan sebagai data independen untuk validasi persamaan. Hasil pengelompokan data TSP tersebut dapat dilihat pada Tabel 2.

Tabel (Table) 2: Pengelompokan data TSP(Grouping of TSP data)

\begin{tabular}{|c|c|c|c|c|}
\hline \multirow[b]{2}{*}{$\begin{array}{c}\text { KPH } \\
\text { (Forest } \\
\text { District) }\end{array}$} & \multirow[b]{2}{*}{$\begin{array}{c}\text { RPH } \\
\text { (Forest } \\
\text { Resort) }\end{array}$} & \multirow[b]{2}{*}{$\begin{array}{l}\text { Petak tanaman } \\
\text { (Compartment) }\end{array}$} & \multicolumn{2}{|c|}{$\begin{array}{c}\text { Jumlah data TSP } \\
\text { (Number of TSP data) }\end{array}$} \\
\hline & & & $\begin{array}{l}\text { Untuk persamaan } \\
\text { regresi } \\
\text { (for regression } \\
\text { equation) }\end{array}$ & $\begin{array}{l}\text { Data independen } \\
\text { (Independent data) }\end{array}$ \\
\hline Sumedang & $\begin{array}{l}\text { Cipelang } \\
\text { Suka Denda } \\
\text { Ujung Jaya } \\
\text { Sempora }\end{array}$ & $\begin{array}{c}43 \\
6 \mathrm{a} \\
30 \mathrm{a} \\
3\end{array}$ & $\begin{array}{l}3 \\
3 \\
3 \\
3\end{array}$ & $\begin{array}{l}1 \\
1 \\
1 \\
1\end{array}$ \\
\hline Kendal & Subah & $\begin{array}{l}25 \mathrm{a} \\
26 \mathrm{a} \\
35 \mathrm{a} \\
36 \mathrm{a}\end{array}$ & $\begin{array}{l}1 \\
2 \\
6 \\
3\end{array}$ & $\begin{array}{l}1 \\
- \\
2 \\
1\end{array}$ \\
\hline Blora & Sumberejo & $\begin{array}{l}108 \mathrm{a} \\
109 \mathrm{c} \\
107 \mathrm{~b} \\
107 \mathrm{a} \\
106 \mathrm{a}\end{array}$ & $\begin{array}{l}3 \\
4 \\
4 \\
3 \\
4\end{array}$ & $\begin{array}{l}2 \\
1 \\
1 \\
2 \\
1\end{array}$ \\
\hline Saradan & Sugihwaras & $\begin{array}{l}5 \mathrm{~b} \\
1 \mathrm{a} \\
5 \mathrm{c} \\
10\end{array}$ & $\begin{array}{l}3 \\
3 \\
2 \\
4\end{array}$ & $\begin{array}{l}1 \\
1 \\
2 \\
-\end{array}$ \\
\hline
\end{tabular}

\section{Tinggi tegakan}

Mengingat pengertian bahwa tinggi pohon adalah nilai rata-rata dari tinggi pohon-pohon penyusun tegakan (Avery dan Burkhart, 2002; serta Husch et al., 2003), maka tinggi tegakan masingmasing TSP dihitung dengan rumus:

$$
H s_{i} \sum \frac{\sum_{j \unrhd}^{n_{i}} H t_{i j}}{n_{i}}
$$

dimana:

$H s_{i} \quad$ : tinggi tegakan pada TSP ke- $i$,

$H t_{i j} \quad$ : tinggi pohon ke-j pada TSP ke- $i$,

$n_{i} \quad$ : jumlah pohon dalam TSP ke- $i$,

$j=1,2,3, \ldots \ldots \ldots \ldots \ldots . . ., n_{i}$. 


\section{Peninggi tegakan}

Mengacu pada kata peninggi adalah nilai rata-rata tinggi sejumlah pohon berdiameter terbesar atau pohon-pohon dominan dan ko-dominan yang letaknya tersebar merata di suatu areal (Alder, 1980; Avery dan Burkhart, 2002; serta Husch et al., 2003), dan istilah peninggi di Indonesia dimaknai sebagai rata-rata tinggi dari pohon-pohon tertinggi yang letaknya tersebar merata dalam 1 hektar areal, maka pada masing-masing plot $10 \mathrm{~m} \times 10 \mathrm{~m}$ di tiap TSP dipilih pohon tertinggi sebagai pohon peninggi, dan peninggi tiap TSP dihitung dengan rumus:

$$
O h_{i} \frac{\sum_{k \unrhd}^{m_{i}} H d_{i k}}{m_{i}}
$$

dimana :

$O h_{i}$ : peninggi tegakan pada $T S P$ ke- $i$,

$m_{i}$ : jumlah plot $(10 \mathrm{~m} \times 10 \mathrm{~m})$ dalam TSP ke-i yang berisi pohon peninggi,

$H d_{i k}$ : tinggi pohon peninggi plot $(10 \mathrm{~m} \times 10 \mathrm{~m}) \mathrm{ke}-k$ dalam $T S P$ ke- $i$,

$k=1,2,3$, $m_{i}$.

\section{Model hubungan tinggi tegakan dengan peninggi}

Model hubungan tinggi tegakan dengan peninggi di masing-masing lokasi penelitian disusun dengan menggunakan data yang dicadangkan untuk menyusun persamaan regresi. Dalam penelitian ini model disusun dalam bentuk persamaan regresi linier sederhana, yaitu:

$$
H s=b_{0}+b_{1} O h
$$

dimana:

$$
\begin{aligned}
H_{s} & : \text { tinggi tegakan }(\mathrm{m}), \\
O h & : \text { peninggi }(\mathrm{m}), \\
b_{1} & : \text { koefisien regresi, } \\
b_{0} & : \text { intersep. }
\end{aligned}
$$

\section{Uji keseragaman persamaan regresi}

Uji keseragaman (homogenity-test) koefisien regresi dari model hubungan $\mathrm{Hs}$-Oh antar lokasi penelitian dilakukan dengan cara sidik ragam seperti ditunjukkan oleh Steel dan Torrie (1980) serta Kutner et al. (2005). Apabila nilai $F$-hitung dari sidik ragam berbeda nyata, maka terindikasi bahwa faktor lokasi mempengaruhi slope (sudut) grafik hubungan $\mathrm{Hs}_{s} \mathrm{Oh}$; dan sebaliknya apabila tidak berbeda nyata maka koefisien-koefisien regresi dapat dinilai seragam.

Uji keseragaman intersep dilakukan dengan menempatkan lokasi penelitian sebagai peubah boneka (dummy variables) seperti dicontohkan oleh Alder(1980).

$$
H s=b_{0}+b_{1} S m d+b_{2} K d l+b_{3} B l a+b_{4} S r d+b_{5} \mathrm{Oh}
$$

dimana:

$H s$ : tinggi tegakan (m), 


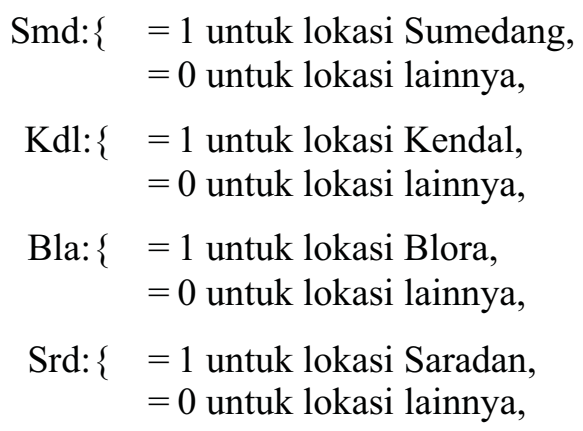

Oh : peninggi (m),

$b_{1}, b_{2}, b_{3}, b_{4}, b_{5}:$ koefisien regresi,

$b_{0} \quad$ : intersep.

Apabila salah satu atau lebih peubah boneka $S m d, K d l$, Bla dan $S r d$ berperan nyata di dalam persamaan, maka hal itu mengindikasikan bahwa faktor lokasi berpengaruh terhadap persamaan. Akan tetapi apabila tidak berperan nyata maka faktor lokasi berkategori seragam, dan perlu dilakukan penyusunan sebuah persamaan dengan data gabungan semua lokasi agar lebih praktis penerapannya di lapangan (penggunaan model $H_{s}$-Oh tidak perlu memperhatikan lokasi).

\section{Uji keabsahan persamaan}

Suatu persamaan regresi dinilai sah apabila ${ }^{1)}$ peubah tidak bergantung (independent variables) berperan signifikan di dalam persamaan (Ryan, 1997; Burnham dan Enderson, 1998; Draper dan Smith, 1998; Montgomery et al., 2001; Belsley et al., 2005; dan Kutner et al., 2005), ${ }^{2)}$ sisaan menyebar normal (Ryan, 1997; dan Montgomery et al., 2001), dan ${ }^{33}$ sebaran sisaan tidak cenderung membentuk trend tertentu (Ryan, 1997; Draper dan Smith, 1998; Montgomery et al., 2001; dan Kutner et al., 2005).

Dalam penelitian ini perhitungan intersep dan koefisien regresi, nilai- $t$ (sebagai indikator berperantidaknya peubah tidak bergantung di dalam persamaan), penggambaran grafik kenormalan sisaan, dan penggambaran grafik sebaran sisaan versus dugaan peubah bergantung dilakukan dengan menggunakan software Minitab Release 14.

\section{Uji kesahihan persamaan}

Merupakan kaidah umum bahwa tingkat kesahihan (validity) suatu persamaan regresi didasarkan pada besarnya koefisien determinasi terkoreksi (adjusted coefficient of determination - $R^{2} a d j$ ) dan kecilnya akar rata-rata kuadrat sisaan (root mean square error - RMSE) (Ryan, 1997; Burnham dan Enderson, 1998; Draper dan Smith 1998; Montgomery et al., 2001; Belsley et al., 2005; Kutner et al., 2005). Selain itu, Shao (1993), Myers (2000), serta Kozak dan Kozak (2003) menyarankan uji silang (cross validation) dengan cara plotting sisaan versus nilai dugaan peubah bergantung didasarkan data independen.

Selain cara uji kesahihan di muka, dalam penelitian ini juga dilakukan uji silang dengan menghitung nilai khi-kuadrat (chi-square) antara nilai $H s$ dugaan versus $H s$ aktual berdasar data independen. Penghitungan nilai khi-kuadrat mengikuti rumus yang disarankan Steel dan Torrie (1980), Sokal dan Rohlf(1995), serta Kutner et al., (2005). 


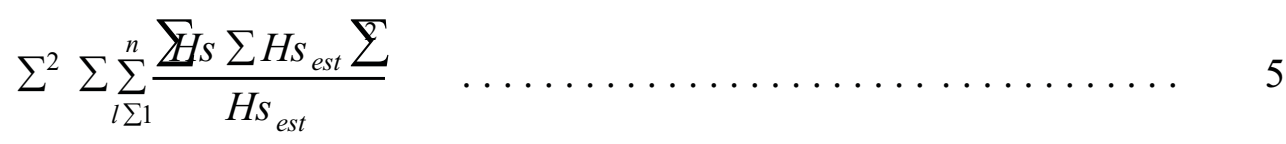

dimana :
$\chi^{2} \quad$ : khi-kuadrat,
$H s$ : tinggi tegakan aktual pada data independen,
$H S_{\text {est }}$ : dugaan tinggi tegakan, dihitung dengan model $H s$ - $O h$ berdasar data $O h$ pada data independen,
$n$ : jumlah TSP data independen.
$l=1,2,3$, ,$n$.

\section{HASIL DAN PEMBAHASAN}

\section{A. Model Hs - Oh di Tiap Lokasi}

Hasil analisis regresi hubungan $H_{s-O h}$ di masing-masing lokasi penelitian dapat dilihat pada Tabel 3 .

Tabel(Table) 3. Persamaan hubungan $H_{s-}$ Oh hutan tanaman Jati di masing-masing lokasi penelitian (Equations of stand height and upper height relationship for teak plantation forest in each study site)

\begin{tabular}{|l|c|c|c|c|c|}
\hline \multicolumn{1}{|c|}{$\begin{array}{c}\text { Lokasi penelitian } \\
\text { (Study site })\end{array}$} & $\begin{array}{c}\text { Persamaan hubungan } H_{s-O h} \\
\left(H_{s-O h} \text { relationship }\right)\end{array}$ & $t_{\text {intercept }}$ & $t_{\text {Oh }}$ & $t_{\text {table }}$ & $R_{\text {adj }}^{2}$ \\
\hline Sumedang & $H s=-2,3463+1,0608$ Oh & $-13,90$ & 110,91 & 2,23 & 0,996 \\
Kendal & $H s=-2,3033+1,0584$ Oh & $-12,64$ & 141,92 & 2,23 & 0,997 \\
Blora & $H s=-2,2565+1,0562$ Oh & $-25,70$ & 342,23 & 2,12 & 0,998 \\
Saradan & $H s=-2,2975+1,0574$ Oh & $-26,07$ & 280,38 & 2,07 & 0,997 \\
\hline
\end{tabular}

Dalam Tabel 3 terlihat bahwa pada hutan tanaman Jati (T. grandis L.f) terdapat hubungan yang sangat nyata antara tinggi tegakan dengan peningginya. Persamaan hubungan $\mathrm{Hs}-\mathrm{Oh}$ di semua lokasi penelitian mempunyai koefisien determinasi $\left(R_{a d j}^{2}\right)$ yang sangat tinggi (lebih dari $99 \%$ ). Hal ini mengindikasikan bahwa di setiap unit hutan tanaman Jati (T. grandis L.f), secara hampir sempurna, keragaman tinggi tegakan dapat diterangkan oleh keragaman peninggi.

Dengan adanya hubungan yang sangat erat antara tinggi tegakan dengan peninggi, maka dalam kegiatan inventarisasi hutan tanaman Jati (T. grandis L.f) pekerjaan pengukuran tinggi pohon dapat dieliminir dengan hanya mengukur tinggi pohon-pohon peninggi. Informasi tinggi tegakan dalam laporan hasil kegiatan inventarisasi secara lebih mudah dapat disajikan dari hasil nilai dugaan dengan menggunakan model hubungan $H_{s-} \mathrm{Oh}$, sehingga terjadi efisiensi pekerjaan pada saat pengukuran $T S P$ TSP.

Besarnya efisiensi pekerjaan pengukuran tinggi pohon pada kegiatan inventarisasi dengan bantuan penggunaan model hubungan $\mathrm{Hs}_{\mathrm{s}} \mathrm{Oh}$ sangat dipengaruhi kerapatan tegakan, yaitu semakin banyak pohon dalam tegakan maka efisiensi yang terjadi akan semakin besar. Sehubungan dengan itu, efisiensi yang terbesar terjadi pada kegiatan inventarisasi tegakan umur muda. Seperti diketahui, pada awal pembangunan hutan tanaman, bibit ditanam dengan jarak tanam relatif rapat kemudian jumlah pohon semakin berkurang seiring dengan pertambahan umur akibat adanya kematian (mortality) maupun tindakan penjarangan. 
Didasarkan data jumlah pohon pada TSP-TSP yang dijadikan bahan penelitian ini, efisiensi pekerjaan pengukuran tinggi pohon dengan bantuan model hubungan $\mathrm{Hs}_{\mathrm{s}} \mathrm{Oh}$ bisa mencapai $\pm 88 \%$ pada tegakan umur 7 tahun, tetapi hanya $\pm 5 \%$ pada tegakan umur 60 tahun, kemudian pada umur-umur selanjutnya tidak terjadi efisiensi. Secara rata-rata total semua umur, efisiensi mencapai $\pm 55 \%$. Grafik besarnya efisiensi menurut umur tegakan dapat dilihat pada Gambar 1.

\begin{tabular}{|c|c|c|c|c|}
\hline $\begin{array}{c}\text { Umur tegakan } \\
\text { (Stand age) } \\
\text { (tahun/years) }\end{array}$ & $N_{T S P}$ & $N_{O h}$ & $\begin{array}{c}\text { Efisiensi } \\
\text { (Efficiency) } \\
(\%)\end{array}$ & $\begin{array}{l}\text { Efficiency (\%) } \\
100\end{array}$ \\
\hline 7 & 135 & 16 & 88 & \\
\hline 12 & 143 & 16 & 89 & \\
\hline 17 & 100 & 16 & 84 & 80 \\
\hline 18 & 74 & 16 & 78 & \\
\hline 19 & 64 & 16 & 75 & 60 \\
\hline 25 & 50 & 16 & 68 & \\
\hline 30 & 41 & 16 & 61 & 40 \\
\hline 35 & 36 & 16 & 55 & \\
\hline 44 & 27 & 16 & 41 & \\
\hline 59 & 17 & 16 & 8 & 20 \\
\hline 65 & 15 & 16 & 0 & \\
\hline 66 & 14 & 16 & 0 & 0 \\
\hline 79 & 13 & 16 & 0 & $\begin{array}{lllllll}0 & 10 & 20 & 30 & 40 & 50 & 60\end{array}$ \\
\hline 108 & 11 & 16 & 0 & Umur tegakan/Stand age (tahun/years) \\
\hline 117 & 10 & 16 & 0 & \\
\hline
\end{tabular}

Gambar(Figure)1. Tabel dan grafik besarnya efisiensi pencurahan tenaga dengan penggunaan model hubungan $\mathrm{Hs}_{s} \mathrm{O} \mathrm{O}$ dibandingkan pengukuran tinggi semua pohon pada inventarisasi hutan tanaman Jati menurut umur tegakan (Table and graph of the manpower efficiency of using the stand height-upper height relationship model compared to the heights of all trees measured in teak plantation inventory againts stand age)

Pada Gambar 1, rata-rata jumlah pohon tegakan umur 7 tahun dalam TSP ukuran $40 \mathrm{~m}$ x $40 \mathrm{~m}$ adalah 135 pohon. Dengan menggunakan model hubungan $H_{s-} \mathrm{Oh}$ maka tinggi tegakan dapat diduga dengan mengukur 16 pohon peninggi, sehingga dibandingkan dengan pengukuran 135 pohon maka terjadi efisiensi $(135-16) / 135 * 100 \%=88 \%$.

\section{B. Analisis Keseragaman Regresi}

Dalam penelitian ini, analisis keseragaman regresi hubungan $H_{s-O h}$ antar lokasi dimaksudkan untuk mengkaji peluang penyusunan sebuah persamaan hubungan $\mathrm{Hs}$-Oh hutan tanaman Jati (T. grandis L.f) yang dapat diberlakukan di semua lokasi sehingga diperoleh kepraktisan karena model tidak perlu disusun pada setiap unit pengelolaan.

Setelah melalui tahap perhitungan sum-product, dan cross-product, analisis keseragaman koefisien regresi hubungan $\mathrm{Hs}_{s} \mathrm{O} \mathrm{O}$ antar lokasi penelitian disajikan dalam Tabel 4. 
Tabel (Table) 4. Analisis keseragaman koefisien regresi persamaan hubungan $H_{s-}-O h$ hutan tanaman Jati antar lokasi penelitian (Homogenity analysis of the regression coefficients of $\mathrm{Hs}$-Oh relationship for teak plantation forest between study sites)

\begin{tabular}{|c|c|c|c|c|c|c|}
\hline $\begin{array}{l}\text { Perlakuan } \\
\text { (Treatment) }\end{array}$ & $\begin{array}{l}\mathrm{db} \\
(d f)\end{array}$ & $\sum x^{2}$ & $\sum x y$ & $\sum y^{2}$ & $\begin{array}{l}\mathrm{db} \\
(d f)\end{array}$ & $\begin{array}{c}\text { JK } \\
\text { tereduksi } \\
\text { (Reduced } \\
\text { sum square) }\end{array}$ \\
\hline Sumedang & 11 & 214,86 & 227,94 & 242,02 & 10 & 0,197 \\
\hline Kendal & 11 & 182,03 & 192,67 & 204,03 & 10 & 0,101 \\
\hline Blora & 17 & 1321,56 & 1395,82 & 1474,46 & 16 & 0,201 \\
\hline Saradan & 23 & 820,56 & 867,69 & 917,79 & 22 & 0,257 \\
\hline \multicolumn{5}{|c|}{$\begin{array}{l}\text { Total sisaan regresi } 4 \text { lokasi } \\
\text { (Residual from individual regressions) }\end{array}$} & 58 & 0,756 \\
\hline $\begin{array}{l}\text { Regresi gabungan } \\
\text { (Total for single regression) }\end{array}$ & 62 & 2539,02 & 2684,13 & 2838,29 & 61 & 0,761 \\
\hline \multicolumn{5}{|c|}{$\begin{array}{l}\text { Beda keseragaman koefisien regresi } \\
\text { (Difference for homogenity of regressions ) }\end{array}$} & 3 & 0,005 \\
\hline
\end{tabular}

Keterangan (Notes) : F hitung $($ calc $)=(0,005 / 3) /(0,756 / 58)=0,12$, tidak berbeda nyata pada taraf $5 \%$ (not significantly different at $5 \%$ level)

Hasil perhitungan nilai- $F$ sebesar 0,12 ternyata jauh lebih kecil dibandingkan nilai $F_{\text {tabel }}$ pada taraf $5 \%$ dengan derajat bebas $(3 ; 58)$ yaitu sebesar 2,76 . Hal ini menunjukkan bahwa koefisien regresi hubungan $\mathrm{Hs}$ - $\mathrm{Oh}$ antar lokasi penelitian adalah seragam (tidak saling berbeda).

Selain keseragaman koefisien regresi, untuk lebih meyakinkan dapat-tidaknya seluruh data dari semua lokasi penelitian digabungkan untuk disusun dalam sebuah persamaan regresi, dalam penelitian ini dikaji berperan-tidaknya faktor lokasi terhadap intersep persamaan. Kajian dilakukan dengan menempatkan lokasi penelitian sebagai peubah boneka (dummy variables) sebagaimana telah disebut dalam Persamaan 4. Hasil perhitungan koefisien regresi serta nilai- $t$ masing-masing peubah dalam bentuk Persamaan 4 dapat dilihat dalam Tabel 5.

Tabel(Table) 5. Koefisien regresi, nilai- $t$, dan peluang masing-masing peubah dari bentuk Persamaan 4 (Regression coefficient, $t$-value, and probability of each variable of $4^{\text {th }}$ equation)

\begin{tabular}{|l|c|c|c|}
\hline $\begin{array}{c}\text { Peubah } \\
\text { (Variable) }\end{array}$ & $\begin{array}{c}\text { Koefisien } \\
\text { (Coefficient) }\end{array}$ & $t$ & $P$ \\
\hline Intersep (Intercept) & $-2,2910$ & $-41,60$ & 0,000 \\
Smd & 0,0087 & 0,21 & 0,833 \\
Kdl & 0,0186 & 0,47 & 0,640 \\
Bla & 0,0085 & 0,24 & 0,814 \\
Srd & - & - & - \\
Oh & 1,0571 & 477,05 & 0,000 \\
\hline
\end{tabular}

Dalam Tabel 5 terlihat bahwa nilai peluang (probability-P) Peubah-Peubah $S m d, K d l$, dan Bla melebihi 0,05. Hal tersebut menunjukkan bahwa faktor lokasi Sumedang, Kendal, dan Blora tidak nyata di dalam persamaan sampai taraf nyata 5\%; bahkan Peubah-Srd (lokasi Saradan) tidak dapat masuk di dalam persamaan karena adanya korelasi sangat tinggi dengan peubah tidak bergantung lainnya. Dengan kata lain, nilai intersep pada semua persamaan yang tercantum dalam Tabel 3 adalah seragam. 
Dengan adanya keseragaman koefisien regresi dan intersep persamaan-persamaan yang tercantum dalam Tabel 3 maka pasangan data $H s$ dan $O h$ di masing-masing lokasi penelitian dapat digabungkan untuk menyusun sebuah persamaan yang berlaku di semua lokasi.

\section{C.Persamaan Tunggal}

Persamaan regresi yang berhasil disusun dengan menggunakan gabungan data dari semua lokasi penelitian adalah Persamaan 6, yaitu:

$$
H s=-2,2852+1,0572 \mathrm{Oh}
$$

\section{Keabsahan Persamaan 6}

Nilai $t_{\text {intersep }}$ dan $t_{\mathrm{Oh}}$ dari Persamaan 6 adalah -49,53 dan 553,99; sedangkan $t$-tabel $\left(t_{0,01(64)}\right)$ adalah 2,65. Perbandingan $t_{\mathrm{Oh}}$ dengan $t$-tabel tersebut mengandung arti bahwa Peubah-Oh sangat nyata berperan dalam persamaan sampai taraf nyata 1\%, sehingga Persamaan 6 memenuhi persyaratan pertama dari kriteria keabsahan persamaan regresi sebagaimana diuraikan dalam Bab II.D.6.

Hasil uji kenormalan dan keaditifan sisaan Persamaan 6 dirangkum pada Gambar 2. Pada bagian kiri Gambar 2, grafik plot hubungan antara sisaan dengan peluang normal cenderung membentuk garis linear dan berada pada diagonal (melewati titik pusat $(0 ; 0)$ ), sehingga dapat disimpulkan bahwa Persamaan 6 memiliki sisaan yang cukup menyebar normal dan memenuhi salah satu kriteria keabsahan persamaan regresi sebagaimana dipersyaratkan oleh Ryan (1997), dan Montgomery etal. (2001).

Pada bagian kanan Gambar 2, grafik plot hubungan sisaan dengan nilai dugaan $H s$ berdasar Persamaan 6 menunjukkan bahwa nilai sisaan menyebar acak dengan pola pita mendatar simetris sepanjang sumbu- $x$. Hal ini menunjukkan bahwa sifat keaditifan terpenuhi karena sisaannya menyebar acak dan memiliki ragam yang homogen, sehingga memenuhi salah satu kriteria keabsahan persamaan regresi sebagaimana dipersyaratkan oleh Ryan (1997), Draper dan Smith, (1998), Montgomery et al. (2001), dan Kutner et al. (2005).

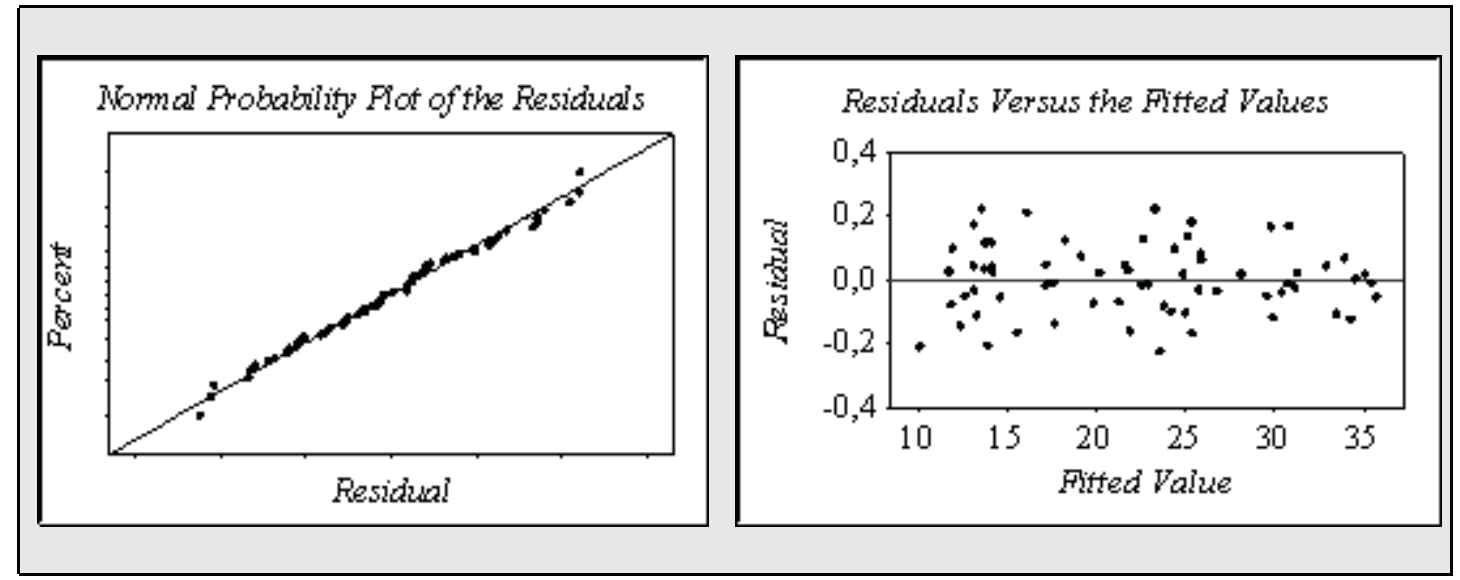

Gambar(Figure)2. Hasil uji kenormalan dan keaditifan sisaan Persamaan-6 (Results of normality and additive tests of the residuals for Equation- 6 ) 
Dengan terpenuhinya 3 persyaratan, yaitu "peubah tidak bergantung berperan nyata di dalam model, ${ }^{2)}$ sisaan menyebar normal, dan ${ }^{3}$ bersifat aditif, maka seluruh persyaratan keabsahan persamaan regresi dipenuhi oleh Persamaan 6.

\section{Kesahihan Persamaan 6}

Persamaan 6 mempunyai koefisien determinasi $\left(R_{a d j}^{2}\right)$ yang sangat tinggi yaitu sebesar 0,998 ; sedangkan nilai $R M S E$ (nilai akar dari rata-rata kuadrat sisaan) sebesar 0,11. Dibandingkan dengan nilai rata-rata $H s$ sebesar 22,16 maka nilai $R M S E$ tersebut tergolong sangat kecil (hanya $0,5 \%$ ). Tingginya $R_{a d j}^{2}$ dan kecilnya nilai RMSE merupakan dasar penilaian bahwa Persamaan 6 dapat dikategorikan sebagai persamaan yang sahih menurut kriteria yang disyaratkan oleh Ryan (1997); Burnham dan Enderson (1998); Draper dan Smith (1998); Montgomery et al. (2001); Belsley et al. (2005); serta Kutner et al. (2005).

Nilai sisaan terbesar dari penerapan Persamaan 6 pada data independen adalah sebesar 0,22 meter pada nilai dugaan 13,32 meter; suatu nilai simpangan yang amat kecil untuk parameter tinggi tegakan. Nilai-nilai sisaan lainnya menyebar dalam bidang berbentuk pita simetris sepanjang sumbu- $x$ dengan amplitudo antara $-0,22$ sampai $+0,22$. Grafik plot hubungan antara sisaan dengan nilai dugaan tinggi tegakan tersebut dapat dilihat dalam Gambar 3. Pola sebaran nilai sisaan dalam Gambar 3 memberikan pengertian bahwa Persamaan 6 memenuhi kriteria kesahihan persamaan regresi yang dijukan oleh Shao (1993); Myers (2000); serta Kozak dan Kozak (2003).

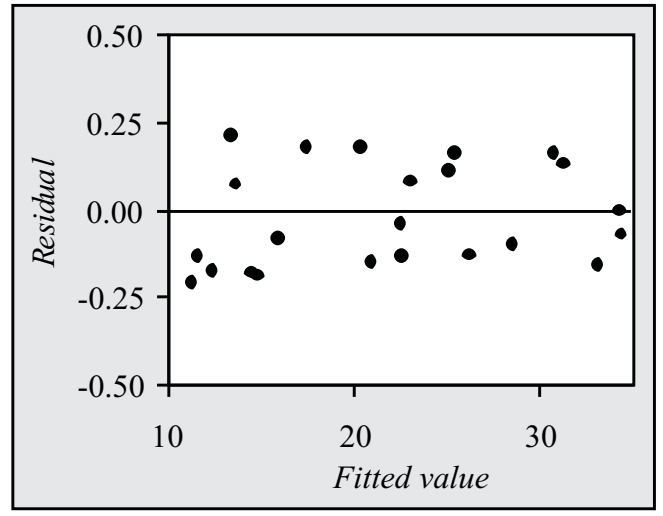

Gambar(Figure) 3. Grafik plot sisaan hubungan antara sisaan dengan nilai dugaan dari penerapan Persamaan 6 pada data independen (Plot of residuals against estimated values for applying Equation 6 using the independent data)

Penerapan Persamaan 6 pada data independen menghasilkan nilai $\chi^{2}$ (khi-kuadrat) sebesar 0,03. Dibandingkan dengan $\chi^{2}$-tabel pada taraf kepercayaan 99\% sebesar 9,54 (derajat bebas $=22$ ), maka terbukti bahwa Persamaan 6 layak dipergunakan untuk praktek lapangan. Dengan kata lain, penggunaan Persamaan 6 untuk menduga tinggi tegakan Jati (T. grandis L.f) dalam praktek inventarisasi hutan mengandung resiko kesalahan dugaan yang kecil.

Tingginya nilai $R_{a d j}^{2}$, kecilnya nilai $R M S E$, sebaran sisaan yang aditif dalam validasi silang (cross validation), dan tidak nyatanya perbedaan nilai dugaan dengan nilai aktual pada uji $\chi^{2}$ dalam cross validation, dapat dijadikan dasar untuk mengkategorikan Persamaan 6 sebagai model yang sahih. 


\section{KESIMPULAN DAN SARAN}

\section{A. Kesimpulan}

1. Model hubungan antara tinggi tegakan $(H s)$ dengan peninggi $(\mathrm{Oh})$ pada hutan tanaman Jati (Tectona grandis L.f) sangat signifikan.

2. Bentuk hubungan $H_{s-O h}$ pada hutan tanaman Jati (T. grandis L.f) tidak berbeda antara unit pengelolaan yang satu dengan unit pengelolaan lainnya.

3. Model matematik hubungan $H_{s}-O h$ hutan tanaman Jati (T. grandis L.f) adalah $H_{s}=-2,2852+$ 1,0572 Oh dengan koefisien determinasi terkoreksi $\left(R_{a d j}^{2}\right)$ sebesar 0,998.

4. Penggunaan model $\mathrm{Hs}_{\mathrm{s}} \mathrm{Oh}$ tersebut pada Butir 3 dalam inventarisasi hutan tanaman Jati (T. grandis L.f) dapat memberikan efisiensi pencurahan tenaga kerja untuk pengukuran tinggi pohon sebesar $\pm 55 \%$; dengan efisiensi terbesar pada tegakan umur muda (di bawah 10 tahun), yaitu mencapai $\pm 88 \%$.

\section{B.Saran}

Efisiensi pencurahan tenaga kerja untuk pengukuran tinggi pohon dalam kegiatan inventarisasi hutan tanaman jenis lain kemungkinan berbeda, sehingga disarankan penelitian semacam ini dilakukan pada hutan tanaman jenis lainnya.

\section{DAFTAR PUSTAKA}

Alder, D. 1980. Forest Volume Estimation and Yield Prediction, FAO, Rome.

Anonim. 1986. Pedoman Penjarangan Hutan Industri. Surat Keputusan Nomor 289/KPTS/DIR/1986. Perum Perhutani, Jakarta.

Anonim. 1997. Rencana Pengaturan Kelestarian Hutan (RPKH) Kelas Perusahaan Jati Kesatuan Pemangkuan Hutan Kendal, Jangka Perusahaan 1 Januari 1998 s/d 31 Desember 2007. Lampiran I, Lembar: 1. Seksi Perencanaan Hutan I Pekalongan, Perum Perhutani Unit I Jawa Tengah, Pekalongan.

Anonim. 2000. Rencana Pengaturan Kelestarian Hutan (RPKH) Kelas Perusahaan Jati Kesatuan Pemangkuan Hutan Sumedang, Jangka Perusahaan 1 Januari 2001 s/d 31 Desember 2010. Lampiran I, Lembar: 1. Seksi Perencanaan Hutan III Cirebon, Perum Perhutani Unit III Jawa Barat, Cirebon.

Anonim. 2003. Rencana Pengaturan Kelestarian Hutan (RPKH) Kelas Perusahaan Jati Kesatuan Pemangkuan Hutan Saradan, Jangka Perusahaan 1 Januari 2004 s/d 31 Desember 2013. Lampiran I, Lembar: 1. Seksi Perencanaan Hutan IV Madiun, Perum Perhutani Unit II Jawa Timur, Madiun.

Anonim. 2004. Rencana Pengaturan Kelestarian Hutan (RPKH) Kelas Perusahaan Jati Kesatuan Pemangkuan Hutan Blora, Jangka Perusahaan 1 Januari 2005 s/d 31 Desember 2014. Lampiran I, Lembar: 1. Seksi Perencanaan Hutan IV Rembang Perum Perhutani Unit I Jawa Tengah, Rembang.

Avery, T. E. and H. E. Burkhart. 2002. Forest Measurements. McGraw-Hill, New York.

Belsley, D. A., E. Kuh and R. E. Welsch. 2005. Regression Diagnostics: Identifying Influential Data and Sources of Collinearity. Wiley-Interscience, Hoboken. 
Burnham, K. P. and D. J. Enderson.1998. Model Selection and Inference: a Practical InformationTheoritic Approach. Springer, Berlin.

Colbert, K. C., D. R. Larsen and J. R. Lootens. 2002. Height-Diameter Equations for Thirteen Midwestern Bottomland Hardwood Species. Northern Journal of Applied Forestry 19, 171-176.

Draper, N. R. and H. Smith. 1998. Applied Regression Analysis. Third Edition. John Wiley \& Sons, Inc, Sydney.

Husch, B., T. W. Beers and J. A. Kershaw. 2003. Forest Mensuration. Fourth Edition. John Wiley and Sons, Inc, New York.

Kozak, A. and R. Kozak. 2003. Does Cross Validation Provide Additional Information in the Evaluation of Regression Models? Canadian Journal of Forest Research 33: 976-987.

Kutner, M. H., C. J. Nachtsheim, J. Neter and W. Li. 2005. Applied Linier Statistical Models. McGrawHill Irwin, Boston.

Montgomery, D. C., E. A. Peck and G. G. Vining. 2001. Introduction to Linear Regression Analysis. Wiley, New York.

Myers, R. H. 2000. Classical and Modern Regression with Applications. Duxbury Press, Belmont.

Ryan, T. P. 1997. Modern Regression Method. Wiley, New York.

Shao, J. 1993. Linear Model Selection by Cross-Validation. Journal of American Statistical Association 88: 486-494.

Sokal, R. R. and F. J. Rohlf. 1995. Biometry: the Principles and Practice of Statistics in Biological Research. W.H. Freeman, New York.

Steel, R. G. D. and J. H. Torrie. 1980. Principles and Procedures of Statistics. Second Edition. McGrawHill Book Company, Inc, New York. 
Lampiran (Appendix) 1. Letak areal penelitian (Research areas location)

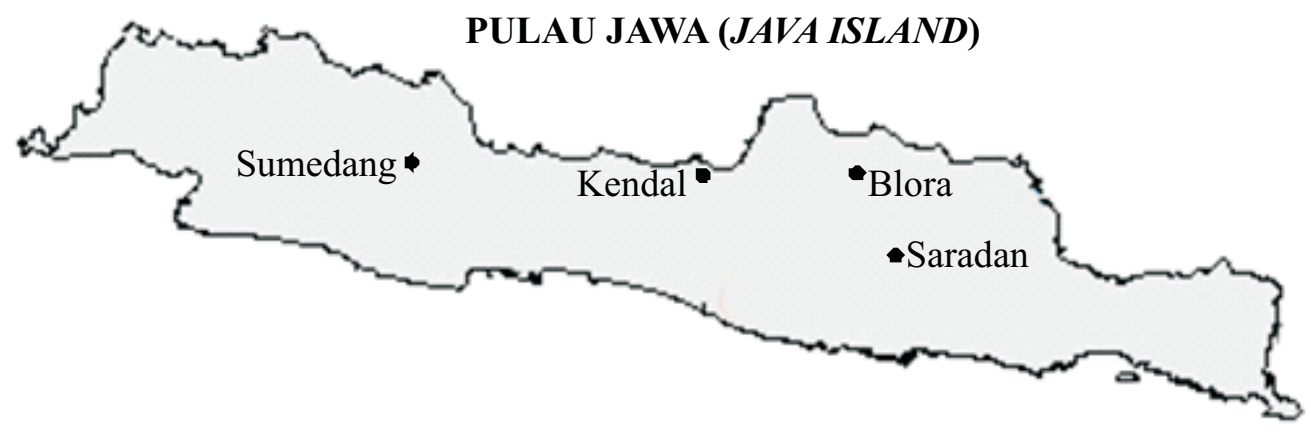

\begin{tabular}{|c|c|c|c|c|}
\hline Uraian (Descriptions) & Sumedang & Kendal & Blora & Saradan \\
\hline $\begin{array}{l}\text { Kesatuan Pemangkuan } \\
\text { Hutan (Forest District) }\end{array}$ & Sumedang & Kendal & Blora & Saradan \\
\hline $\begin{array}{l}\text { Bagian Kesatuan } \\
\text { Pemangkuan Hutan \& } \\
\text { Resort Polisi Hutan (Sub } \\
\text { Forest District \& Forest } \\
\text { Resort) }\end{array}$ & $\begin{array}{l}\text { Conggeang: } \\
\text { - Cipelang } \\
\text { - Sampora } \\
\text { Buahdua } \\
\text { - Sukadenda } \\
\text { Ujungjaya } \\
\text { - Ujungjaya }\end{array}$ & $\begin{array}{l}\text { Subah: } \\
\text { - Subah }\end{array}$ & $\begin{array}{l}\text { Nglawungan: } \\
\text { - Sumberejo }\end{array}$ & $\begin{array}{l}\text { Wilangan } \\
\text { Utara: } \\
\text { - Sugihwaras }\end{array}$ \\
\hline Propinsi (Province) & $\begin{array}{l}\text { Jawa Barat } \\
\text { (West Java) }\end{array}$ & $\begin{array}{l}\text { Jawa Tengah } \\
\text { (Central } \\
\text { Java) }\end{array}$ & $\begin{array}{l}\text { Jawa Tengah } \\
\text { (Central } \\
\text { Java) }\end{array}$ & $\begin{array}{l}\text { Jawa Timur } \\
\text { (East Java) }\end{array}$ \\
\hline Kabupaten (District) & Sumedang & Batang & Blora & Madiun \\
\hline $\begin{array}{l}\text { Kecamatan \& Desa } \\
\text { (Sub District \& Village) }\end{array}$ & $\begin{array}{l}\text { Conggeang: } \\
\text { - Babakan } \\
\text { Asem } \\
\text { Buahdua } \\
\text { - Gendereh } \\
\text { Ujungjaya } \\
\text { - Sakurjaya }\end{array}$ & $\begin{array}{l}\text { Subah: } \\
\text { - Subah } \\
\text { - Adisono }\end{array}$ & $\begin{array}{l}\text { Japah: } \\
\text { - Sumberejo } \\
\text { - Ngiyono }\end{array}$ & $\begin{array}{l}\text { Saradan: } \\
\text { - Sidorejo }\end{array}$ \\
\hline
\end{tabular}


Lampiran(Appendix) 2. Deskripsi keadaan lingkungan areal penelitian (Environment descriptions of research area)

\section{KPH Sumedang (Perum Perhutani Unit III Jawa Barat dan Banten)}

$\sum$ Geografis

Tinggi tempat (altitude) antara 25-80 meter di atas permukaan laut ( $\mathrm{m} \mathrm{dpl}$ ) dengan topografi pada umumnya datar (lereng $=8 \%$ ) hanya sedikit (di Ujungjaya) bergelombang dengan lereng $=30 \%$.

$\sum \underline{\text { Kondisitanah }}$ Jenis tanah di BKPH Conggeang adalah asosiasi latosol coklat dan regosol kelabu; di BKPH Buahdua asosiasi latosol merah, latosol coklat kemerahan dan laterit air tanah; dan di BKPH Ujungjaya grumusol kelabu (Anonim, 2000).

$\sum \underline{\text { Kondisi iklim }}$

Curah hujan rata-rata sebesar $2.598 \mathrm{~mm} /$ tahun dengan hari hujan sebanyak 158 hari termasuk tipe C dengan nilai Q sebesar $57,89 \%$. Suhu harian antara $26^{\circ} \mathrm{C}-37^{\circ} \mathrm{C}$ (Anonim, 2000).

\section{KPH Kendal (Perum Perhutani Unit I Jawa Tengah)}

$\sum \underline{\text { Geografis }}$

Petak-petak tanaman yang dijadikan lokasi penelitian berada pada ketinggian 200-250 m dpl, dengan topografi bergelombang (lereng bervariasi 0-30\%).

$\sum \underline{\text { Kondisitanah }}$

Tanah di wilayah BKPH Subah termasuk jenis latosol, pada umumnya bertekstur sedang hingga liat dengan struktur remah hingga bergumpal (Anonim, 1997).

$\sum$ Kondisi iklim

Rata-rata curah hujan tahunan $1.942 \mathrm{~mm}$ termasuk tipe $\mathrm{C}$ dengan nilai $\mathrm{Q}=46,3 \%$. Suhu rata-rata harian $26^{\circ} \mathrm{C}$ (Anonim, 1997).

\section{KPH Blora (Perum Perhutani Unit I Jawa Tengah)}

$\sum$ Geografis

Tinggi tempat berkisar antara 100-190 $\mathrm{m}$ dpl dengan konfigurasi lapangan bervariasi dari datar (lereng $=8 \%$ ) sampai bergelombang (lereng $=30 \%$ ).

$\sum \underline{\text { Kondisitanah }}$ Jenis tanah asosiasi mediteran merah kekuningan dan mediteran coklat kekuningan (Anonim, 2004).

$\sum \underline{\text { Kondisi iklim }}$ Curah hujan termasuk tipe $\mathrm{C}$, dengan rata-rata tahunan $1.060 \mathrm{~mm}-1.644 \mathrm{~mm}$. Kelembaban nisbi $80 \%$, dengan amplitudo suhu harian $26^{\circ} \mathrm{C} 37^{\circ} \mathrm{C}$ (Anonim, 2004).

\section{KPH Saradan (Perum Perhutani Unit II Jawa Timur)}

$\sum$ Geografis

Ketinggian lokasi penelitian $\pm 150 \mathrm{~m} \mathrm{dpl}$, dengan topografi datar (lereng $=8 \%$ ).

$\sum \underline{\text { Kondisitanah }}$ Jenis tanah di BKPH Wilangan Utara adalah grumusol kelabu tua dengan bahan induk tuf volkan intermedier (Anonim, 2003).

$\sum \underline{\text { Kondisi iklim }}$

Kondisi curah hujan termasuk tipe D dengan nilai Q sebesar 94\% (Anonim, 2003). 